\title{
King Lear on the Arabic Stage: Linguistic, Social and Cultural Considerations
}

\author{
Fatima M. Muhaidat \\ The Hashemite University, Jordan \\ Shadi S. Neimneh \\ The Hashemite University, Jordan \\ Elham T. Hussein \\ Ha'il University, Saudi Arabia
}

\begin{abstract}
This paper discusses the challenges translators face when rendering Shakespeare's King Lear into Arabic. Issues considered include metaphor, diction, classical references, and social titles. Our strategy depends on finding out examples of the distinctive features of Shakespearean style and comparing them with their counterpart $s$ in two Arabic translations of the play by Jabra Ibrahim Jabra and Fatima Moussa Mahmoud. Comparisons reflect various problems translators face when conveying Shakespearian language into Arabic. For example, some imagery, especially personification of abstract ideas, is either absent or modified. Such deletions and changes render the target text less effective. Translators also adopt different approaches in translating classical references relating to Roman gods. While Jabra adopts foreignization as he keeps the feel of the source text by transliterating a number of these references, Mahmoud naturalizes them by giving Arabic paraphrases. The advantages and pitfalls of each technique are evaluated to find out what aspects of the ST are rendered into Arabic and which ones are not given priority. Contextual factors involved in the decision making process are discussed to illuminate the complex nature of translation. Problems of translating social titles appear when one finds that the same title is given different renderings in different parts of the play. Shakespearean diction causes certain problems due to the absence of one-to-one word equivalence. The need to take audience's social and cultural background into consideration makes translators avoid literal renderings. Explanations and better renderings are suggested to provide the Arab audience with a better access to Shakespeare and enrich translators' knowledge of their multifaceted task.
\end{abstract}

Index Terms - translation, Renaissance drama, imagery, classical references, culture, world literature, Shakespeare, King Lear

\section{INTRODUCTION}

William Shakespeare's portrayal of the vicissitudes of human experience has gained him a special place in World Literature. His distinguished treatment of universal themes has brought him eternal fame, and his readership records attest to his worldwide outreach. His plays have invaded the stage outside the English-speaking world. This paper discusses the challenges involved in translating Shakespeare's King Lear into Arabic. In this play, Shakespeare excels in reflecting the fluctuations of what is usually supposed and expected to be the strongest, closest, and most stable human relationship, parent-child relationship. Action is based on a conflict between a father (King Lear) and his three daughters. Misunderstanding, misinterpretation, and misjudgment play significant roles in determining relationships among characters. The play further shows the power of language when used as a mask to hide real intentions. The tragedy reveals what is at stake when judgments are based on words rather than deeds.

\section{SHAKESPEARIAN LANGUAGE AND TRANSLATION}

Translating Shakespeare into Arabic poses several challenges. Written about four hundred years ago, the text stands aloof before its audiences - even those whose mother tongue is English. Annotations, handbooks, footnotes, and study guides are common resorts for both researchers and students entering the playwright's world. Since reading is an integral element of translation, we deem it appropriate to mention characteristics of Shakespearean language that make it defy easy reading. Related to this point, Sean McEvoy (2000, pp. 11-58) discusses different factors that make reading Shakespeare a demanding task. McEvoy (pp. 11-14) explains that Shakespeare addresses an audience of good listeners as the majority of them could neither read nor write. Compared with today's listeners, they had more advanced listening skills. They needed such skills to capture the import of what they listened to because, otherwise, they had no other means to access it. Thus, one finds long speeches with patterns of language having "distinctive rhythms and repetitions of words, phrases and ways of saying things" (McEvoy, p. 13). Another challenge readers and translators of Shakespeare face is the change that occurs to lexical items (McEvoy, pp. 14-18). Some of the words have died out. 
Others express meanings different from those they express today. Awareness of these lexical and semantic shifts is needed for a good reading, and consequently an adequate translation.

Furthermore, drama and literature in general avoid literal or straightforward narration and description of action. Shakespearian texts are rich in figurative language including "images, comparisons, and analogies" (McEvoy, p. 28). King Lear abounds with imagery including personification of abstract ideas and other metaphors. Recognizing the function of these figures of speech and conveying it into the target text is necessary. Otherwise, a significant element of the source text remains unveiled. A translation lacking important aspects of the original text is likely to deprive its audience of the privileges entailed in interlingual and intercultural communication. The importance of metaphor is articulated by Stefano Arduini (1998) who states that "the metaphor is not simply a 'coating' but an indispensible instrument of knowledge and, as such, does not possess an indirect meaning"(p. 198). This suggests that metaphors are not mere linguistic ornaments to make the text more elegant. This point of view agrees with that of "cognitive linguists" who are in favor of looking at metaphor as "cognition" rather than "expression" (Gerard Steen, 1994, p. 5). Put differently, metaphor is more than a stylistic feature prettifying language.

In addition to referring to abstract ideas in terms of human or living creatures, metaphors in King Lear include imagery of supernatural creatures. Furthermore, elements of nature are sometimes described as human beings. In her experiment in simulated literary translation, Barbara Romaine (2003) attributes the challenging nature of Shakespearian language to being "poetic and highly figurative" and speaks of its ellipses and metaphors as "more opaque by the fact that much of the language is ... archaic" (p.19).

More challenges appear when considering that Shakespeare varies his language depending on the situation, effect, and impression he makes. For instance, he writes King Lear in blank verse and prose. One finds that the same character may use either mode in different parts of the play. Thus, translators have the task of rendering the variations that occur in character speeches. Some variations are triggered by the circumstances under which these speeches take place. They often give clues about speaker's mood and relationship between speaker and addressee(s). Commenting on poetry translation, Eugene Nida (2001) explains,

It must be recognized that in translating poetry there are very special problems involved, for the form of expression (rhythm, meter, assonance, etc.) is essential to communicating the spirit of the message to the audience. But all translating, whether of poetry or prose, must be concerned also with the response of the receptor; hence the ultimate purpose of the translation, in terms of its impact upon its intended audience, is a fundamental factor in any evaluation of translations. (p.131)

Nida pinpoints the conflict that translators usually have to solve, especially when dealing with poetry. Translators have sometimes to choose between either preserving features of the ST or sacrificing them for the sake of renderings that give priority to audience reception of the TT. Nida is in favor of the second option which is likely to compromise the "form" of the ST.

Our study reflects differences in the options Jabra and Mahmoud make. By and large, the former's literal renditions speak of his faithfulness to the ST, whereas the latter's choices reflect a tendency to impress her audience. She does not hesitate to smoothly reach them by means of naturalizing the ST and in turn using equivalent Arabic expressions without necessarily adhering to the diction of the ST. By contrast, Jabra's literal equivalents can be sometimes confusing or they sound odd. Despite these problems, both translations unveil different aspects of the play. Both translators should be credited for giving readers/viewers in Arabic an opportunity to explore avenues to the playwright's boundless horizons.

\section{METAPHOR}

King Lear is rich in figurative language. Imaginative portrayals of characters, human action, feelings, and mental states pervade the text. Metaphors include comparisons that express an idea in terms of another. David Mikics (2007) uses Donald Richardson's definition which refers to metaphor as "a figure of thought and of speech that makes us see one thing as another" (pp.180-181). The significance of metaphors lies in the effectiveness of expressing experiences in special ways that draw similarities and associations between dissimilar or seemingly unrelated notions. The propriety and novelty of such comparisons are functional. Unexpected connection of ideas is likely to attract audience attention to its fresh tinge of meaning. According to Mikics (2007), "Its compactness makes it both profitable and thrifty; it seems to offer the reader a bonus of meaning" (p.181). Thus, metaphors are effective as they can have the advantage of conveying extra input in fewer words.

Certain mental processes like analysis and evaluation are involved in capturing meaningful messages in creative metaphorical combinations. D.A. Cruse (1986) explains that "The metaphorical strategy of interpretation is most likely to be triggered off by a perception of incongruity or inappropriateness in the sentence when interpreted literally" (p. 42). This mental experience boosts the text-audience relationship as it contributes to the intellectual pleasure felt in reading the text or watching it performed. Thus, readers or viewers simultaneously learn and enjoy the time spent in the author's world. In other words, metaphor can add to the beauty and charm of a text through well-built imagery and modes of expression that do more than straightforwardly convey information. Success in thought expression not only depends on what is said, but also on how it is said. 
This section is dedicated to the translation of various examples of metaphors. What attracts us is Shakespeare's personification of abstract ideas. Aspects of human behavior like curiosity, friendship, ingratitude, and shame are given human traits. We deal with personifications as metaphors since the definition above applies to them. They make readers/viewers see abstractions as human beings. A variety of translation techniques are needed to convey Shakespearian style into Arabic.

If the opening lines of King Lear suggest anything, they attest to Shakespeare as "a master of the dramatic opening scene" (Fenella and Gamini Salgado, 1986, p.11). Distinctive choice of lexical items, personification, and sound effects combine to show important elements of the plot and introduce major characters. Gloucester and Kent start the scene discussing what went in their minds about Lear's preferring Duke Albany, his older son-in-law, to Duke Cornwall. It occurs to both speakers that the King would give a better part for the former. Contrary to their expectations, the Dukes' shares reflect the king's impartiality. In this regard, Gloucester says,

ST1: for equalities are so weighed that curiosity in neither can make choice of either's moiety. (I. i)

TT1a: laqad wazana baina ashumihima bihaith annahuma mahma daqqaqa falan yastatee'a an yufadhila baina alhussataini. (Jabra: 229)

BT1a: Indeed, he gave them equal shares; thus, no matter how closely they examine (their shares), they will not be able to decide which one is better.

TT1b: fa alansibatu mutasawiyatu tamaman, wa la majala li shubhati tafdheel. (Mahmoud I. i)

BT1b: Thus, the shares are exactly equal, and there is no possibility for suspicions of preference.

According to the source text (ST), the king succeeds in striking a balance between the portions of his in-laws. Each is satisfied with his own share. Rather than coming haphazardly or being imposed by a high authority, this satisfaction mirrors inner convictions in both sides. In Shakespeare's language, inner forces that may give rise to conflicts are silenced by the equity the king has achieved. One sentence conveys this achievement. The first clause expresses the careful distribution of possessions really intended to achieve equality. The effectiveness of the Shakespearian expression becomes more evident when considering the metaphor (personification) in the second clause. Gloucester uses the noun "curiosity" as the subject of the verbal construction "can make" in the relative clause above. In other words, an abstract notion appears as a person who is unable to choose between two good options.

This image of an abstract idea (curiosity) as human being does not appear in the TTs. Jabra's translation includes three intricately interconnected sentences. The first one is verbal starting with the emphatic "laqad" (indeed) preceding the verb "wazana" (made equal). The doer of the action is a hidden pronoun "huwa" (he) referring to King Lear. The verb is followed by a prepositional phrase which literally means "between the shares of both." The connector "bihayth" (thus) leads readers to the second sentence. It is nominal as it starts with the emphatic particle "anna" (Indeed) followed by the pronoun "huma" (both) working as the subject. Immediately, one is introduced into the third sentence. Interestingly it works as the predicate of the second sentence. The third sentence is conditional. It expresses the idea implied in the clause containing the metaphor in the ST. No reference is made to an abstract idea performing a mental process. It rather mentions that no matter how both of them (the Dukes of Albany and Cornwall) closely examine their shares, they will not be able to tell which part is better. Put differently, instead of referring to abstract ideas "making choice," this rendering mentions human beings trying to make judgment about two good options.

As for Mahmoud's rendering, the complex sentence is rendered into two sentences in Arabic. Both of them are nominal. The first sentence expresses the meaning of the first clause in English. However, the TT mainly states that the shares are equal without including any reference to the meticulous distribution suggested in the English "so weighed." The polysemous connector "fa" (thus/as) is used to achieve coherence. In this context, it explains and justifies the opinion that the king treats his in-laws equally. Another connector "wa" (and) is used between the sentences in the TT. Unlike its counterpart, the second sentence includes no metaphors. It rather starts with the particle "la" negating any possibility for thoughts inviting suspicions about the king's impartiality. This rendering achieves brevity at the expense of the imagery in English. A significant stylistic feature is sacrificed and the audience in Arabic is not exposed to Shakespeare's way of personifying abstract ideas.

In addition to personification, choice of lexical items endows the text with sound effects as "curiosity" rhymes with "moiety." This combination of stylistic features strengthens the text's appeal to audience's imagination and senses via imagery as well as melodic effects. The playwright's choice of "moiety," a word borrowed from Latin, further enriches his text. This is reminiscent of a significant aspect of the Renaissance and its interest in classical learning.

We suggest the following rendering to keep the metaphor:

Fa'ayyu tadqeeqin min altarafain lan yu'ifa ayyan minhuma fi ikhtiyari ayyin mina alhussatain.

BT: for any close examination on the part of the two sides will not help either of them make choice of either share.

More personifications pose further challenges to translators. Gloucester is disappointed at the drastic course events take with the royal family. The King disinherits Cordelia because he does not like the way she expresses her love for him. Kent is also banished because he disagrees with the King on the way Cordelia is punished. Kent's efforts to make the King change his mind go in vain. Gloucester says,

ST2: Friendship falls off. (I. ii)

TT2: Wa alasdiqa'u yatamarradoon. (Jabra: 246)

BT2: And friends rebel. 
Friendship, an abstract idea, is vividly described as someone or something that "falls off." The verb "fall off" suggests meanings like "withdraw, backfire, betray, decrease, fall down (from a tree)." In Shakespeare's language, failure in friendship is associated with going backward, getting unfavorable results, betrayal, shrinking, and falling. No metaphor appears in Arabic. While the part of conversation including the sentence is deleted in Mahmoud's rendering, the plural "friends" is given as a counterpart to "friendship" by Jabra. Thus, he highlights the human aspect of this relationship while English places it in an abstract position. The effectiveness of the TT recedes more as the verb "yatamarrad" (rebel) does not convey all the shades suggested by "fall off." The verb in Arabic, for example, lacks the sad associations of fruits falling off trees. Death, separation, and loss of vitality are just some of the shades encompassed in the image in the ST. Imagery adds to the worth of the text as friendship is one of the central themes in the play. Hence, translators are expected to bear in mind that form and content intertwine to bring about a powerful text with memorable effects. Absence of imagery in the TT renders it less vivid and less expressive. We suggest the following rendering:

Wa tanharu alsadaqatu.

BT: And friendship collapses.

Although our rendering suggests the destruction caused by friendship failure, it does not explicitly convey the tinges of rebellious, mutinous behavior and betrayal felt in its English counterpart. The difficulty of rendering all aspects of the ST brings to mind the notion that "all translation is only a somewhat provisional way of coming to terms with the foreignness of languages" (Walter Benjamin, 2001, p.19). Having full access to the ST in one version is unlikely to happen no matter how translators grapple with the potential that text offers. Fortunately, this possibility can motivate other translators to uncover further avenues of the same text.

Ingratitude is a significant theme in the play. Metaphorical portrayals of ingratitude express character frustrations. Shocked by the way his daughter Gonerel deliberately mistreats him, King Lear expresses his disappointment and anger. He says,

ST3: Ingratitude, thou marble-hearted fiend, (I. iv)

TT3a: ayyuha al'uqooq, ya shaitanan qalbuhu min rukham. (Jabra: 260)

BT3a: O, ingratitude. O, fiend whose heart is (made) of marble.

TT3b: ayyuha al'uqooq, ana shaitanun qudda qalbuka min sakhr. (Mahmoud: I. iii)

BT3b: O, ingratitude, you are a fiend with a heart cut out of rock.

Comparing the two renderings of "marble-hearted," one finds that Jabra adopts formal equivalence and keeps the image of marble in "qalbuhu min rukham" (his heart is made of marble). We think that this literal rendering can be confusing since the word "rukham" (marble) is used in Arabic to express deceptive appearances which is not intended at this point. The expression is uttered at a time when Gonerel shamelessly and openly deals with her father's men as an annoyance. Rather than referring to deceptive appearance, the metaphor conveys the merciless and cruel treatment the king receives at the hand of his daughter. As for Mahmoud, she resorts to functional equivalence. She aptly uses "sakhr" (rock) as an equivalent to "marble." This image is commonly used in Arabic to express lack of emotions. Her choice indicates her closeness to her audience. Interestingly, both translators render "ingratitude" into "oqooq" commonly used in religious and didactic discourse to refer to one's misbehavior or disobedience to parents.

People's tendency to imbue nature with mysterious good or evil powers inspires Shakespeare's imagination. Edmund inflames his father's rage at his brother Edgar by telling lies about the latter's resorting to magic and seeking extraordinary support from nature. After a fabricated fight ending in a fake injury, Edmund persuades Edgar to run away to avoid the sentence of death. In a conversation with his father, Edmund fabricates the following account of that encounter:

ST4: Here stood he in the dark, his sharp sword out, Mumbling of wicked charms, conjuring the moon To stand auspicious mistress. (II, i)

TT4: tarabbasa huna fi aldhalami, wa saifuhu almadhi masloolun, Wa huwa yutamtimu bi ta'aweetha shirreeratin, muheeban bil qamari an yuhsina fa'lahu. (Jabra: 269)

BT4: He lurked here in the dark with his sharp sword drawn, Mumbling of evil charms, appealing to the moon To be optimistic.

To bring about a convincing relation of the event, Edmund does not limit himself to drawing a dramatic scene encompassed in darkness and violence. He rather adds a sense of mystery represented in uttering indistinguishable words to gain supernatural effects, and seeking good luck from nature. Although Jabra manages to capture the atmosphere of the ST, a challenge arises as the moon is personified as a female figure that Edgar appeals to for help. The associations and emotiveness of this image are not fully expressed in Arabic which views the moon as a male figure. In the TT, Edgar asks the moon to be optimistic. Thus, a metaphor is used in Arabic although it is not as vivid as its counterpart. Due to differences in the way the moon is personified, there is no image of the moon as a mistress portending success.

More metaphors express strong human feelings. Edgar's alleged attempt on his father's life brings to the foreground Regan's prejudice against her father. She cunningly draws a connection between Edgar's assumed conspiracy and her father who names him. She expresses suspicions that her father's knights are engaged in enticing Edgar to kill Gloucester. Unfortunately, the latter takes the bait. In response to her, he says 
ST5: O, lady, lady, shame would have it hid! (II, i)

TT5a: Ah ya sayyidati, aktumu thalika khashyata al'ari. (Jabra: 271)

BT5a: Oh, (vocative particle) my lady. I hide that in fear of shame.

TT5b: innani min shiddati khajali atamanna an okhfi hatha al'amr. (Mahmoud: I. iv)

BT5b: Indeed, I am so terribly ashamed that I wish to hide this matter.

In the ST, the vocative mode, repetition, and metaphor express the speaker's sadness, disappointment, embarrassment and rage. The metaphor draws an effective image of shame itself being so ashamed of Edgar's deeds that it would have them unrevealed. In other words, an abstract notion "shame" is personified as someone who "would have hid" Edgar's evil. Jabra's attempts to give access to the playwright's style are obvious. For example, the vocative mode and repetition appear in his rendering with some modifications. While English repeats the noun "lady," his version uses two vocative particles "Ah" $(\mathrm{Oh})$ and "ya" which convey the speaker's sad mood. It also includes the possessive pronoun "y" (my) attached at the end of "sayyidah" (lady). This pronoun expresses respect, care, and closeness. English uses the pronoun "it" to refer to Edgar's plotting while Jabra uses the demonstrative "thalika" (that). However, no metaphor appears in Arabic. A verbal sentence starting with "aktumu" (I hide) expresses its meaning. Thus, a hidden (implicit) pronoun (I) works as the doer of the action. The object is "thalika" (that) which refers to Edgar's alleged attempt to take his father's life. The object is followed by the causative object which is a governing word "khishyata" (in fear of) followed by "al'ar" (shame) the governed noun of the genitive construction. Hence, by sacrificing metaphor, the enlivening effect of personification is lost rendering the TT less appealing.

Metaphor is also absent in Mahmoud's rendering. Instead of personification, the speaker straightforwardly conveys his feelings of embarrassment that make him wish to hide his son's alleged conspiracy.

Rendering the metaphor into Arabic is important since it highlights the way Gloucester starts to feel about his two sons. A significant change is noticed in the mood of the father who used to blush to acknowledge the illegitimate Edmond. Upon Gloucester's request, Edgar has now to face the sentence of death with procedures taken to give Edmund inheritance rights. These procedures mark the beginning of Gloucester's downfall which leads to his consequent suffering and loss of eyesight. We suggest the following rendering to keep the metaphorical touch of the ST: Inna al 'ara kan layuwari wajhahu min fi'latih.

BT: Indeed, shame would have his face hidden because of his deed.

Imagery also figures in descriptions of the deterioration in the mental state of the king. Referring to his condition, Kent says

ST6: All the power of his wits have [sic] given way to his impatience. (III, vi)

TT6: nafatha sabruhu fa inharat quwa rushdihi (Jabra: 313)

BT6: He ran out of patience, so his mental powers collapsed.

The ST strongly expresses the sympathy of the speaker. The King's problem is portrayed as an internal encounter between two opposing traits, "wits" and "impatience." Using the predeterminer "all" indicates the speaker's awareness of the gloomy and serious condition of his friend. The pain the King feels because of his daughters' ingratitude impacts all his mental powers which include "common sense, imagination, fantasy, estimation, and memory" (William Shakespeare, 2008, p.134). The verb "given way" conveys the notion of "wits" receding before impatience which seems to win the conflict and take command of the King's mind. This image of withdrawal does not appear in Arabic. The TT conveys the King's plight in two sentences connected by the coordinating conjunction "fa" which expresses a causeeffect relationship. The first sentence mentions the cause "running out of patience," and the second one mentions the result "the collapse of mental powers." This rendering is less vivid than its counterpart as it lacks the image of two forces competing to control the king's mind and mood. Our suggestion is:

Istaslamat quwa sawabihi kulliha amam qillati sabrihi.

BT: All his mental powers have given way to his impatience.

The discussion above illustrates the problems involved in translating metaphors. Various personifications of abstract ideas are not kept in Arabic. Literal renderings can be confusing. Although we have suggested some renderings to better convey the messages in the ST, some aspects of Shakespearean metaphorical expressions remain unattainable in Arabic.

\section{Social Titles}

Courtesy is a significant aspect of Renaissance dialogues. Social titles figure in conversations throughout the play. Such titles are sometimes noticed in interactions between family members or friends. In the opening scene and upon seeing Edmond with Gloucester, Kent keeps titles when asking his friend about his son. He says,

ST1: Is not this your son, my lord?

TT1a: alaisa hatha ibnuka ya mawlay? (Jabra: 229)

BT1a: Is not this your son, my lord?

TT1b: 'afwan ya sadeeqi, hal alfata ibnuk? (Mahmoud: I. i)

BT1b: Excuse me/pardon me my friend! Is the young man your son?

Comparing the two renderings above, one realizes that the first one keeps the formality of the ST, whereas the second one switches register. Jabra's option illustrates his tendency to give priority to text, so he opts for "mawlay," a very formal title that can be used in addressing a king. It can also be used in religious discourse to address God. As for the 
second rendering, one finds a less formal mode of address. First, the speaker uses the word "'afwan" (excuse me) which makes it more appropriate to ask about whether the young man he sees is his addressee's son or not. Second, no formal titles appear in the conversation as "sadeeqi" (my friend) is given as an equivalent to "my lord." This suggests that priority here is given to audience. It may sound odd in Arabic to hear the word "mawlay" used among friends as both of them are acquaintances of the king. However, the attention given to audience has resulted in sacrificing the spirit of the Renaissance pervading the ST.

Other examples show the difficulties involved in translating social titles. One notices the inconsistency in conveying the title "lord" into Arabic. For instance, "My Lord of Kent" (I. i) is rendered by Jabra into "sayyidi allord Kent (p. 229)" (sir/my master Lord Kent), transliterating the title and adding "sayyidi" (sir/my master). Mahmoud transliterates it into "Lord Kent (I. i)" without any additions. In another example, the phrase "the Lords of France and Burgundy" (I. i) is rendered by Jabra into "douq faransa wa douq bugundia" (p. 230). This means that the title is replaced by another one applying to characters in other parts of the play. However, this rendering may be inaccurate as the play mentions the king, not the Duke of France. Mahmoud uses a similar strategy giving "ameerayy faransa wa burgundia (I. i)" (the two princes of France and Burgundy). This choice is more accurate as France and Burgundy are referred to as princes by King Lear himself. Furthermore, "My Lord of Burgundy" (I. i) is rendered into "ya azeezi ameer Burgundia" (Jabra: 237) (My dear prince of Burgundy). Not only does Jabra vary his translation of the title, but he also adds "dear" which makes the conversation more intimate. This addition seems to express the intimacy felt in the pronoun "my." Mahmoud's rendering is "sayyidi ameer burgundy" (I. i) (Sir/my master prince of Burgundy). What is added "sayyidi" (my master) is more formal than "dear." Both additions by both translators mirror efforts to reflect aspects of the ST.

Renaissance courtesy appears in family interactions. "I will fitly bring you to hear my lord speak" (I. ii) is rendered by Jabra as "to make preparations for you to hear my father talk" (p. 247). Here, Edmund refers to his father as his lord. This observance of formality even among family members is not kept in Arabic. Again, readers/viewers of the text in Arabic have no clues about the significance of hierarchy in English society during the Renaissance. It could be that Edmund keeps the title when conversing with his brother to fulfill his own goals by ascertaining his respect and devotion to his father. His mode of address may prevent any suspicions regarding his secret plotting. This maneuvering is not felt in Arabic as the speaker uses no titles in reference to his father. Avoiding oddness could be behind translator's choice.

Different methods of translation are used to deal with other titles. An example is the title "duke." The sentence "the Duke of Cornwall and Regan his duchess will be here" (II. i) is rendered into "doaq Cornwall wa "aqeelatihi Regan sayakoonani huna" (Jabra: 267). (The Duke of Cornwall and his wife Regan will be here). In Jabra's translation, the feminine form of the title "duchess" becomes "aqeeltuhu" a formal word referring to the wife of a man of a high rank. Brevity could be behind sacrificing the title. Another problem appears when translating the plural "Dukes." Jabra renders the phrase "the Dukes of Cornwall and Albany" (II. i) into "doaq Cornwall wa doaq Albany" (p. 267). The singular form "doaq" is repeated as no plural of the title is used in the Arabic.

The examples above reflect several challenges involved in translating social titles into Arabic. The two translators give different renderings for the same title. Furthermore, inconsistency in rendering the same title by the same translator reflects the difficulty of finding a word for word equivalent for it. Other problems include the absence of a plural form of some of these titles. We believe that sacrificing social titles deprives TT audience of an important concern in Renaissance writings which is order and power. Sean McEvoy (2000) explains, "Crowns, thrones and rich robes on public display were of course important parts of this, but so were the rituals and the formal language of power" (p. 200). Observing courtesy rules is a manifestation of respect for established order and its authority.

\section{CHOICE OF LEXICAL ITEMS}

Diction choice creates a web of semantic associations and sound effects. Although action is set in pagan England, Gloucester's experience of having an illegitimate son was not without its own frustrations and inconveniences. Gloucester says,

ST1: I have so often blushed to acknowledge him that now I am brazed to it. (I.i )

TT1a: latalama khajiltu bili'tirafi bihi hatta bittu la astahi min thalik. (Jabra: 229)

BT1a: Many times I felt so embarrassed to acknowledge him that I don't feel shy of that.

TT1b: katheeran ma ihmarra wajhi mina al'I'tirafi bil amri hatta nuhissa bil khajal. (Mahmoud: I. i)

BT1b: Many times my face got red when acknowledging the matter until we feel shy.

Differences in lexicalization of meaning gives rise to translation problems. English uses the word "blushed" which expresses shyness as well as the color of the speaker's face as it reddens with embarrassment. Jabra opts for "khajiltu," a verb which means "felt shy." However, this verb does not convey the color red which indicates the speaker's inability to hide the discomfort that shows on his countenance. Mahmoud paraphrases the verb into two words "ihmarra wajhi" (my face got red). Her strategy effectively highlights the color element without explicitly referring to "shyness" which is understood from context. As for the word "brazed" (hardened), it conveys the change in Gloucester's mood towards acknowledging his illegitimate son. Neither the element of hardening nor the alliteration in "blushed" and "brazed" appears in the TTs. Jabra's "I don't feel shy" reflects the change in the speakers feeling but it lacks the "hardness" 
suggested by "brazed." Regarding Mahmoud's rendering of "brazed," we find that the phrase "hatta nuhissa bilkhjal" (until we feel shy) is confusing.

Using Mahmoud's rendering of "blushed," our suggested rendering goes as follows:

Wa katheeran ma ihmarra wajhi mina ali'tirafi bihi hatta sirtu aissian la astahi min thalika.

BT: And many times my face became red to acknowledge him until I became invincible/hard not feeling shy of it.

Contextual factors shed more light on translator's decisions and choices. Right from the beginning, Shakespeare makes his audience aware of the strong relationship between Gloucester and his illegitimate son. Through sense of humor, readers' attention is attracted to the speaker's story about his mistress. When Gloucester talks about his sons, he remembers the good old days of his love affair that results in having his illegitimate son Edmond. Gloucester says,

ST2: But I have a son, sir, by order of law, some year elder Than this, who yet is no dearer in my account. Though This knave came something saucily into the world before He was sent for, yet was his mother fair; there was good Sport at his making, and the whoreson must be acknowledged.

TT2a: Wa lakinna lee ibnan shar'iyyan, ya sayyidi, yakburu hatha bizuha'i sanatan, a'azza alayya minhu. Ja'a hatha alfata ila alddunya ma'a ba'dhi almujooni qabla an ursila fi talabih, ghaira anna ummahu kanat jameelatan. Wa kana lana fi sun'ihi lahwun wa mut'atun, fala'atarifu bi ibni alzaniyati. (Jabra: 229)

BT2a: But I have a legitimate son, sir, about one year older than this and dearer to me. This young man came to this world with some impudence before I send for him. But his mother was beautiful, and we had fun and joy in his making. So let me acknowledge the son of adultress.

TT2b: 'ala anna lee ibnan akhara shar'iyyan- yakburu hatha bisanatin taqreeban, wa lakinnahu laysa a'azza indi minhu, wa law anna hatha al'ifreeta ja'a ila aldunia bijasaratin doona an yatlubahu ahad, illa anna ummahu kanat hulwatan wa kanat ayyamuha mumti'atan, wa la budda an a'tarifa bi ibni alkhaleelati hatha ikraman laha. (Mahmoud: I. i)

BT2b: But I have another son who is legitimate and about one year older than him. However, he is not dearer to me although this afreet/demon came to the world boldly without anyone seeking him. Still, his mother was pretty and her days were joyous, and I must acknowledge this son of mistress for her sake.

Various translation issues arise when comparing the ST with its counterparts. First, the negation in "no dearer" is not conveyed in Jabra's translation. This negation is significant as it introduces an important aspect of the speaker's character. Actually, Gloucester sadly orchestrates his own tragedy as he blindly loves and trusts his illegitimate son. Not being aware, from the beginning, that Gloucester loves his illegitimate son Edmund more than his older legitimate one may confuse readers or viewers of the play in Arabic. As for Mahmoud's rendering, it successfully conveys the father's preference. Second, translators differ in rendering the word "knave" which conveys associations like deception, being unprincipled or crafty fellow. It also indicates a man of a humble birth. Gloucester playfully uses the word to refer to his favorite son. Humorously, the word conveys the atmosphere in which Edmond was born. Unexpectedly he comes to this life as his father has a love affair for the sake of fun rather than having children. Connotations of humble birth also apply here. Later, one notices that Edmond's awareness of his birth background torments him. The man's bitter feelings even trigger his plotting against his brother. All these associations are lost in Jabra's rendering since it includes a lexical item "fata" (young man) commonly used in formal discourse. This rendering suggests youth, and, unlike its counterpart, it has no indications about social background, unusual skills, or circumstances of one's birth. Therefore, the audience of the TT has no glimpse of the sense of humor felt in the ST.

To capture the humor and associations of "knave," Mahmoud uses "'ifreet" (demon), a supernatural creature with extraordinary powers usually mentioned in fairy tales. This rendering conveys some shades of "knave" like craftiness and deception. At the same time, the TT incorporates an imaginary creature not mentioned in the Shakespearian text. Contrary to what is said about Edmund, this creature is usually not handsome, and could be mentioned to scare small children in the hope of making them avoid something bad. Despite these discrepancies, we think that the contrast between what is said and what is seen about Edmund's countenance contributes to the sense of humor felt in Gloucester's words. Furthermore, introducing an extraordinary element helps attract readers/viewers attention to the play. Translator's choice shows her awareness of the need to achieve an effect similar to the one intended by the ST even if the literal meaning of the lexical item she chooses is not identical to that in the ST.

The cultural background of the audience is one of the factors successful translators should take into consideration. Let us consider the differences between the two renderings of the sentence "there was good sport at his making, and the whoreson must be acknowledged." Jabra shows a tendency to be faithful to the words of the ST. In "Wa kana lana fi sun'ihi lahwun wa mut'atun" (we had fun and joy in his making), he directly refers to joy and fun the speaker feels in having a relationship thwarting acceptable social norms. Adherence to the ST is also noticed in rendering "whoreson" into "ibni alzaniyati" (son of adultress). It seems that the word "whoreson" gives rise to humor in English. By contrast, we believe that Jabra's rendering does not give a similar effect as the phrase is derogatory and insulting in Arabic. Using it in the opening scene of a play that may attract families and viewers from various backgrounds can be offensive. Such considerations may have triggered less direct references to inappropriate behavior and its perpetrators. For example, instead of (we had fun and joy in his making), Mahmoud opts for "wa kanat ayyamuha mumti'atan" (her days were joyous). Evading direct reference to taboos makes the language more acceptable and less offensive. A similar strategy appears in rendering "whoreson" into "ibni alkhaleelati" (son of mistress). We believe that this phrase is less 
offensive because of the associations of the word "khaleelah" with friendship. Mahmoud adds the phrase "ikraman laha" (for her sake) which clearly justifies the commitment of the father towards his son. Shunning offensive words conveys the playfulness of the scene.

The analysis above reveals various translation problems Shakespearean lexical items pose. There is no one-to-one equivalence between words in the ST and their counterparts in Arabic. In addition, sound effects are likely to be lost in translation. Literal renderings may produce offensive or unacceptable rendering. Thus, translators should take the social and cultural background of their audience into consideration. This usually results in renderings that change certain aspects of the ST. The difficulty of finding an equivalent may lead to less appealing renderings. However, these obstacles should not keep translators from continuing their mission.

\section{Classical ReFERENCES}

Classical references in King Lear include words referring to Roman gods. Such references coincide with the pagan atmosphere in which action takes place. In addition, they illustrate the spirit of the Renaissance in Shakespeare. Incorporating aspects of Roman and Greek civilizations is expected at a time witnessing an interest in classical learning and philosophy. Sean McEvoy (2000) indicates the rise of a group of "intellectuals" who believed that "through careful reading of Greek and Roman texts they could recover the understanding of the world which, they thought, made ancient times superior to their own" (p. 155). Translators differ in rendering classical elements. To get a glimpse of these differences, some examples of Shakespearian classical references are compared with their counterparts in Arabic.

Cordelia chooses to be honest rather than hypocrite. Instead of claiming that her heart has no place for anyone other than her father, Cordelia states that she loves him and owes him due respect and honor. However, misinterpreting her brevity and frankness, King Lear is enraged by her answer. Consequently, he disinherits her and banishes her. The following is the oath he takes in this regard.

ST1: For, by the sacred radiance of the sun, The mysteries of Hecate and the night, (I. i)

TT1a: qasaman bi dhiya'i alshamsi almuqaddasi, wa asrari hakati wa allayli, (Jabra: 233)

BT1a: I swear by the holy sunlight and the mysteries of Hecate and the night,

TT1b:oqsimu bi noori alshamsi wa rabbati alssihri (Mahmoud: I. i)

BT1b: I swear by the sunlight and the goddess of witchcraft.

One notices different renderings of "Hecate" (goddess of witchcraft). Jabra transliterates the name into Arabic. He also uses a footnote explaining the name and its connections with the underworld and witchcraft. Jabra's faithfulness to the ST is evident as he renders every single word into Arabic. Unlike Jabra, Mahmoud uses "rabbati alsihri" (goddess of magic/witchcraft). Thus, rather than acquainting the Arab audience with the foreign name mentioned in the ST, she paraphrases it offering a direct access to its referent. Clarity and brevity justify her choice.

ST2: Now by Apollo

TT2a: qasaman bi Apollo (Jabra: 236)

BT2a: I swear by Apollo

TT2b: qasaman bi alshams. (Mahmoud: I.i)

BT2b: I swear by the sun.

While Jabra transliterates "Apollo" and explains in a footnote that the name is one of the several pagan references mentioned throughout the play, Mahmoud renders it into "alshams" (the sun). Swearing by anything or anyone other than God is not acceptable from an Islamic point of view. Using a nonreligious oath, Mahmoud's rendering conveys the pagan atmosphere of the play. Thus, in two different ways, the TT audience can feel the pagan element. Again translators' options illustrate the former's tendency to foreignize his translation, and the latter's willingness to naturalize it. However, neither Jabra nor Mahmoud refer to Apollo as the god of music and poetry. In other words, certain aspects are lost in translation.

ST3: By Jupiter, (I. i)

TT3a: qasaman bi Jupiter. (Jabra: 237)

BT3a: I swear by Jupiter.

TT3b:fa wa Allahi. (Mahmoud: I.i)

BT3b: By Allah (God).

Without using footnotes, Jabra transliterates "Jupiter" into Arabic. Mahmoud renders it into "Allah" (God). Changing a pagan oath into a religious one reflects the translator's cultural background and closeness to her audience. The need to take the TT audience into consideration is expressed by Carla Di Franco (2000) who states "Constructions in the target text are formed not only with the source text and its intended meaning in mind, but also with the target text audience and the modification or translation of the message from the source to the target language" (pp. 372-373). In addition to the change from a pagan mode of expression to a religious one, both renderings avoid any reference to Jupiter as the king of the gods in Roman mythology. Eliding certain details is a reminder of the sacrifices that may be inevitable in translation.

The examples above reflect the difficulty of rendering classical references into Arabic. Footnotes are needed in a written rendering when the names are transliterated. In performance, paraphrasing these names make the text accessible 
to TT audience. However, the foreignness indicating the origin of these names disappears. Thus, the TT loses the classical touch which is a significant aspect of Renaissance writings.

\section{CONCLUSION}

Shakespearean language in King Lear poses different translation problems. Considering the renderings by Jabra and Mahmoud, we have found certain differences in their approaches. Jabra reflects a tendency to convey the ST diction, while Mahmoud never falters in her efforts to reach her audience. Most personifications in the previous examples are not kept in the TT. Jabra paraphrases them. Unlike the ST, instead of describing abstract ideas in terms of human beings, he rather substitutes the abstract ideas with human figures. This substitution causes loss of the enlivening effect that personification offers. Mahmoud's renderings of the same stylistic feature show that she paraphrases it in some examples, and deletes it in others. Deletions may be attributed to time constraints. Twenty-first century audience may not have the time that Renaissance audience had for entertainment.

More differences can be noticed between the TTs and their counterparts. Some metaphors are rendered literally by Jabra. Such literal renderings may be confusing as they may include images with associations not intended by the ST. Certain challenges result from differences in the way languages view the world. A metaphor can be effective and emotive in English. However, it becomes less emotive because its image is viewed differently in Arabic. These differences show the sacrifices involved in translation. Rather than adhering to the words of the ST, Mahmood sometimes opts for metaphors used in Arabic to convey similar messages. Her choices coincide with her focus on modes of expression familiar to her audience.

Social titles in King Lear are functional. They reflect the importance of observing courtesy rules in Renaissance society. They can also be seen as manifestations of the themes of order and power in the play. Problems involved in their translation include resorting to different renderings for the same title. This indeterminacy can be attributed to the polysemous nature of some of them. Different strategies like paraphrasing and transliteration are used to render these titles.

Shakespearian diction and its intricate associations pose different translation challenges. Emotive and humorous portrayals are rendered less effectively due to the difficulty of finding words conveying the connotations in English. Another challenge is the loss of sound effects in translation. Classical references referring to gods show clear distinctions between Jabra and Mahmoud. While the former transliterates them and uses footnotes to show their origins, the latter paraphrases them. Again Jabra's emphasis on conveying the feel of the ST is evident. His approach differs from Mahmoud's audience-oriented translation.

These differences in translators' options and techniques are reminiscent of the complexity of their task. Translation is a process in which contextual factors like text type, author, and audience have to be taken into consideration. Jabra's rendering is useful for students and researchers interested in Shakespeare's language. As for Mahmoud's version of the play, it has been well received by its audience. It has successfully attracted viewers for about eight years.

\section{REFERENCES}

[1] Arduini, S. (1998). Translating Metaphors and Intercultural Communication. In Abdullah Shunnaq, Cay Dollerup, and Mohammed Saraireh (Eds.), Issues in Translation A Refereed Book (pp. 189-204). Irbid: Irbid National University \& Jordanian Translators' Association.

[2] Benjamin, W. (2000). The Task of the Translator: An introduction to the translation of Baudelaire's Tableaux Parisiens. In Lawrence Venuti (Ed.), (Harry Zohn, Trans.), The Translation Studies Reader (pp. 15-25). London: Routledge.

[3] Cruse, D. A. (1986). Lexical Semantics. Cambridge: Cambridge University Press.

[4] Franco, C. D. (2000). Translation and the Theory View. In Marilyn Gaddis Rose (Ed.), Beyond the Western Tradition: Translation Perspectives XI (pp. 371-391). Binghamton: State University of New York.

[5] McEvoy, S. (2000). Shakespeare: The Basics. London and New York: Routledge.

[6] Mikics, D. (2007). A New Handbook of Literary Terms. New Haven: Yale University Press. Retrieved October 23, 2012, from http://site.ebrary.com/lib/hashemiteu/Doc?id=10210186

[7] Nida, E. (2000). Principles of Correspondence. In Lawrence Venuti (Ed.), The Translation Studies Reader (pp. 126-140). London: Routledge.

[8] Romaine, B. (2003). On Writing in Tongues: An Experiment in Simulated Literary Translation. Translation Review, 65, 16-22.

[9] Salgado, F. and G. (1986). Othello. England: Penguin Books.

[10] Shakespeare, W. (2008). King Lear. Beirut: York Press.

[11] Steen, G. (1994). Understanding Metaphor in Literature: An Empirical Approach. London: Longman.

[12] Shakespeare, W. (2000). The Great Tragedies: Hamlet, Othello, King Lear, and Macbeth. (Jabra Ibrahim Jabra, Trans). Beirut: Al Mu'assassah Al-Arabiyyah lildirasati wa alnashr.

[13] www.youtube.com (King Lear translated into Arabic by Dr. Fatima Moussa). Retrieved April, 23, 2012, from http://www.youtube.com/results?search_query 
Fatima M. Muhaidat has a Ph.D. in comparative literature from Binghamton University (USA), 2006. She works as an assistant professor in the department of English language and literature at Hashemite University, Jordan. Her research interests lie in literary translation and cultural studies.

Shadi S. Neimneh has a Ph.D. in literary and cultural studies from Oklahoma University (USA), 2011. He is currently the assistant dean in the faculty of arts at Hashemite University, Jordan, and an assistant professor in the English department. Dr. Neimneh has published numerous articles in international journals on South African literature and literary modernism.

Elham T. Hussein has a Ph.D. from Purdue University (USA), 2006. She is an assistant professor of literature at the University of Ha'il in Saudi Arabia where she teaches a wide scope of literary and cultural courses. Dr. Hussein has published a number of articles on criticism and culture in Qatar. 